Gustav Horn, Camille Logeay, Katja Rietzler*

\title{
Much Ado about Nothing? Recent Labour Market Reforms in Germany - a Preliminary Assessment ${ }^{* *}$
}

The article examines the macroeconomic effects of the recent labour market reforms in Germany. The reforms increased the downward pressure on wages and led to rising income inequality. Many German economists welcomed this effect, because they consider lower wages and higher wage dispersion major prerequisites for stronger employment growth. The theoretical analysis shows that a strategy of wage restraint might make sense in a small open economy, where exports play a dominating role. However, in a large and less open economy the negative effects of wage restraint on domestic demand are likely to outweigh the positive effects of enhanced competitiveness as could be observed in Germany in recent years. A comparison of the most recent two upswings confirms that the labour intensity of growth has not risen since the reforms. At the same time German wage restraint has contributed to increasing trade imbalances in the euro area.

Key words: Labour market reforms, wage restraint, employment, business cycle

* Macroeconomic Policy Institute (IMK) at the Hans Böckler Foundation in Düsseldorf, Germany. Katja Rietzler, who left the IMK at the end of 2007, works free-lance in Hannover. E-mail: Gustav-Horn@BOECKLER.DE.

** Article received: November 31, 2007

Revised version accepted after double blind review: May 29, 2008. 


\section{Introduction}

The decisive economic policy issue for the German government in 2003 was how to overcome the deep and persistent economic slump the German economy had dived into after 2001. Low if any growth, surging public deficits and rising unemployment rates then were the dominant economic tendencies. The economic policy debate focused on solutions to all these problems. Since high unemployment had proved very persistent in recent cycles, a major policy change was called for by most German economists. Instead of focusing on stimulating the goods market, the remedy to these problems was sought in the labour market. These developments led to a government reform programme called Agenda 2010. ${ }^{1}$ The target was to create a more flexible labour market that should stimulate employment and growth.

At the end of 2004, the economy took a turn for the better although at the beginning the upturn was rather weak. However, in due course growth accelerated and employment expanded rapidly, too. The question is whether the Agenda 2010 has made a contribution to this positive development. The paper attempts to find a preliminary answer since the upturn was not yet over at the end of 2007 when this paper was completed. In order to derive meaningful results, one has to compare employment performance across business cycles. The present cycle in which reforms have already been implemented is compared to the preceding cycle at the end of the nineties well before the Agenda 2010. Several aspects of labour market performance are analysed.

The basic conclusion of this article is that the upturn was not triggered by labour market reforms. Although the employment record of the latest upturn has been slightly better than that of the preceding one, growth has not been more labour intensive and differences have been rather small. At the same time the reforms have had an adverse effect on domestic demand. Thus the assessment of the reforms remains mixed.

\section{Some theoretical considerations on labour market reforms}

The predominant diagnosis since the early nineties has been that the German labour market was too rigid to deal with challenges of the global economy (OECD 1994; SVR 2002; Sinn 2003). The roots of the rigidity are seen in an overly generous social security system and in a wage bargaining system where trade unions have an excessive influence especially in the low wage segment. According to this view, both institutional settings have contributed to high and persistent unemployment.

The generous social security system is said to have diminished the incentives for the unemployed to look for a job (SVR 2002, Ziffer 433 ff.; Sinn et al. 2006). The unemployed draw higher utility from their leisure than from employment given the relatively high benefit level. According to this view, rational unemployed persons see no need to accept job offers that would lead to only marginally higher incomes. In other words, the reservation wage is seen as too high leading to prolonged periods of un-

1 Governmental address by Chancellor Schröder March, 14 2003, http://archiv.bundesregierung.de/artikel/81/557981/attachment/557980_0.pdf 
employment. Moreover, the costs of the social security system lead to a high tax wedge, which in turn increases labour costs and therefore diminishes labour demand. A high tax wedge also reduces labour supply since net wages are lower, leading to a lower utility of work. This also weakens the incentive to seek employment.

The same result is derived along the second line of argument. Strong trade union influence allegedly leads to an excessively narrow wage dispersion. Unions are assumed to be interested not only in high wages but also in high wage equality among their members. Therefore they bargain for excessively high wages particularly at the lower end of the wage range. As a result, these wages are too high to create enough demand for less-qualified labour since its productivity is lower than the price (i.e. wages) firms have to pay (SVR 2002, Ziffer 347-349 and 353-354).

While on the one hand, high wages increase the incentives for the unemployed to seek work, it is said that on the other hand, this is offset by too generous social benefits, which increase reservation wages. The negative effect is assumed to dominate and the result is a stubbornly high unemployment rate, especially for people with low qualifications.

The recommended economic policy strategy to overcome this situation is a reform of the social security system as well as of the wage bargaining process. The first should lower the reservation wage and decrease the tax wedge. Then, incentives to search for employment would be reinforced, the supply of labour would increase as well as the demand for labour through diminishing labour costs. The second reform measure is expected to lead to lower wages on average and a higher wage dispersion. It should therefore raise labour demand in general, but especially for low qualified jobs.

The impact of all these measures can be illustrated in the following graph (Bassanini/Duval 2006, 19; Box 1).

\section{Figure 1:}

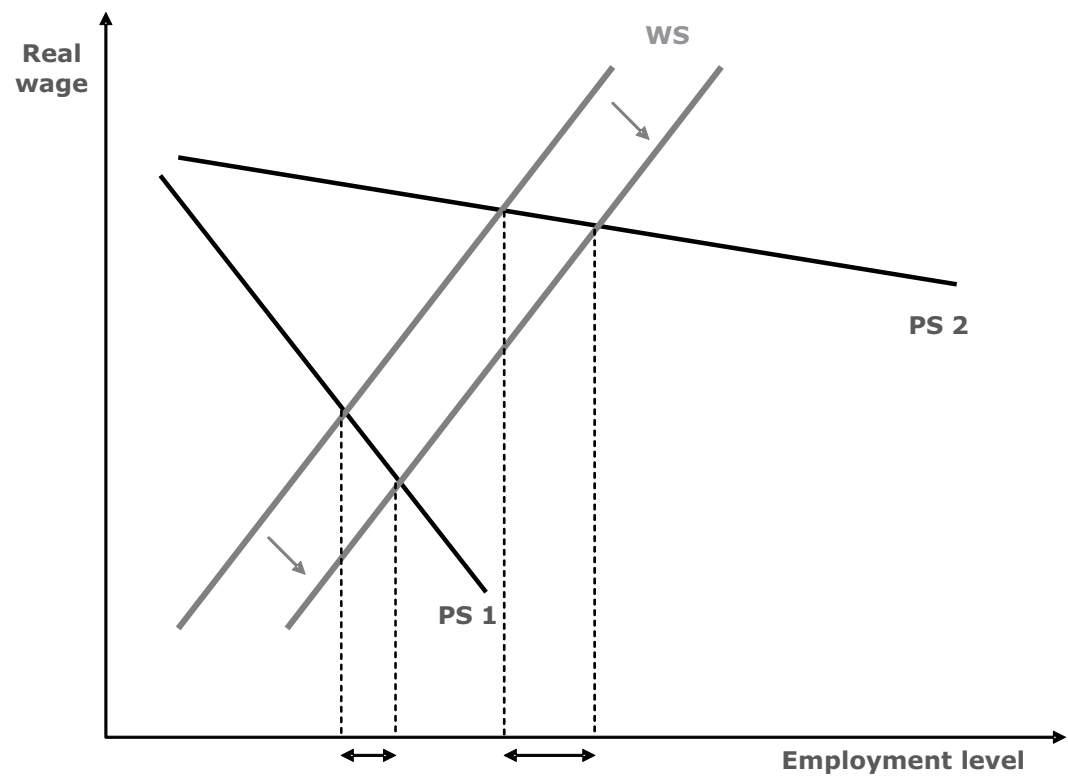


The graph describes a usual price and wage setting approach. The models assume imperfect competition in goods and labour markets. Therefore prices and wages are set by market participants. The setting of wages and prices determines real wages on the one side and as a consequence, in most usual approaches (Layard et al. 1991), employment on the other side (right-to-manage).

The graph shows the relationship between real wages and employment that can be derived from these models. The slope of the price-setting curve is negative, because higher prices lead to lower real wages leading to higher labour demand. The slope of the wage setting curve is positive, since higher employment increases the market power of workers leading to higher wages and thus to higher real wages. An aggregate equilibrium is achieved at the intersection of both curves. At the equilibrium point, real wages satisfy both firms' and workers' requirements (i.e. utility and profits). The battle of mark-up is over! (Layard et al. 1991; Carlin/Soskice 1990)

Labour market reforms weakening the influence of trade unions and lowering the reservation wage should lead to a downward shift of the wage-setting curve (arrays on the WS-curves). With less union bargaining power, real wages will be lower if all other influences remain equal. In this setting, employment will rise (arrays on the $\mathrm{X}$-axis). The effect can be reinforced if it is accompanied by product market reforms that shift price setting curve PS upward too, due to a more intensive competition (as a result the PS-curve would be flatter as in PS2).

The reform package laid down in the recent German reforms (Job-AQTIV implemented in 2002 and followed by the Hartz-reforms started in 2003 till 2005 plus additional changes) focused on labour market reforms only ${ }^{2}$. The theoretical foundations outlined above were derived from supply side macroeconomic models. In these models, following a neoclassical line of thinking, the equilibrium of the goods market i.e. of the overall economic activity is determined by supply side variables only. Hence, the productivity of labour is the only criterion for employment. Supply side factors determine the outcome in the goods market and simultaneously in the labour market. Therefore, only supply side measures are necessary to foster employment (Sinn 2005; SVR 2005, Ziffer 232). That is basically what the OECD already recommended in its famous jobs study in 1994 (OECD 1994).

The inclusion of demand changes the pattern how labour market reforms affect employment. Then the wage dampening impact of the reforms does not only affect the supply side, but also weakens demand. In this setting, the ambivalent character of wages is revealed. On the one hand, they are costs and firms have to minimise them in order to become or stay competitive. On the other hand, they are the basis of labour income, which in turn is the strongest root of demand and in particular of consumption. Two cases have to be distinguished (Carlin/Soskice 2007). The first one is a small and open economy that produces mainly for exports. In such an economy wage restraint induced by labour market reforms will create an unequivocal increase of unemployment. Real wages fall, this makes labour cheaper and at the same time enhances international competitiveness. Therefore foreign demand for domestic prod-

2 These are well summarised by their own motto; "Fördern und Fordern" or "Assist \& Insist"-principles. 
ucts, and thus (net) exports, will rise too. Since (net) exports are the dominant demand factor in a small open economy, the overall demand effect is positive. Hence in case of a small open economy labour market reforms should clearly lead to lower unemployment as the cost aspect dominates.

A different pattern emerges in a large and/or less open economy, where domestic demand dominates. In this case there is still a positive impact of lower real wages, but the overall effect of labour market reforms on demand is negative (Carlin/Soskice 2007). This is shown in the graph developed by Carlin/Soskice (2007:120) below.

Figure 2:

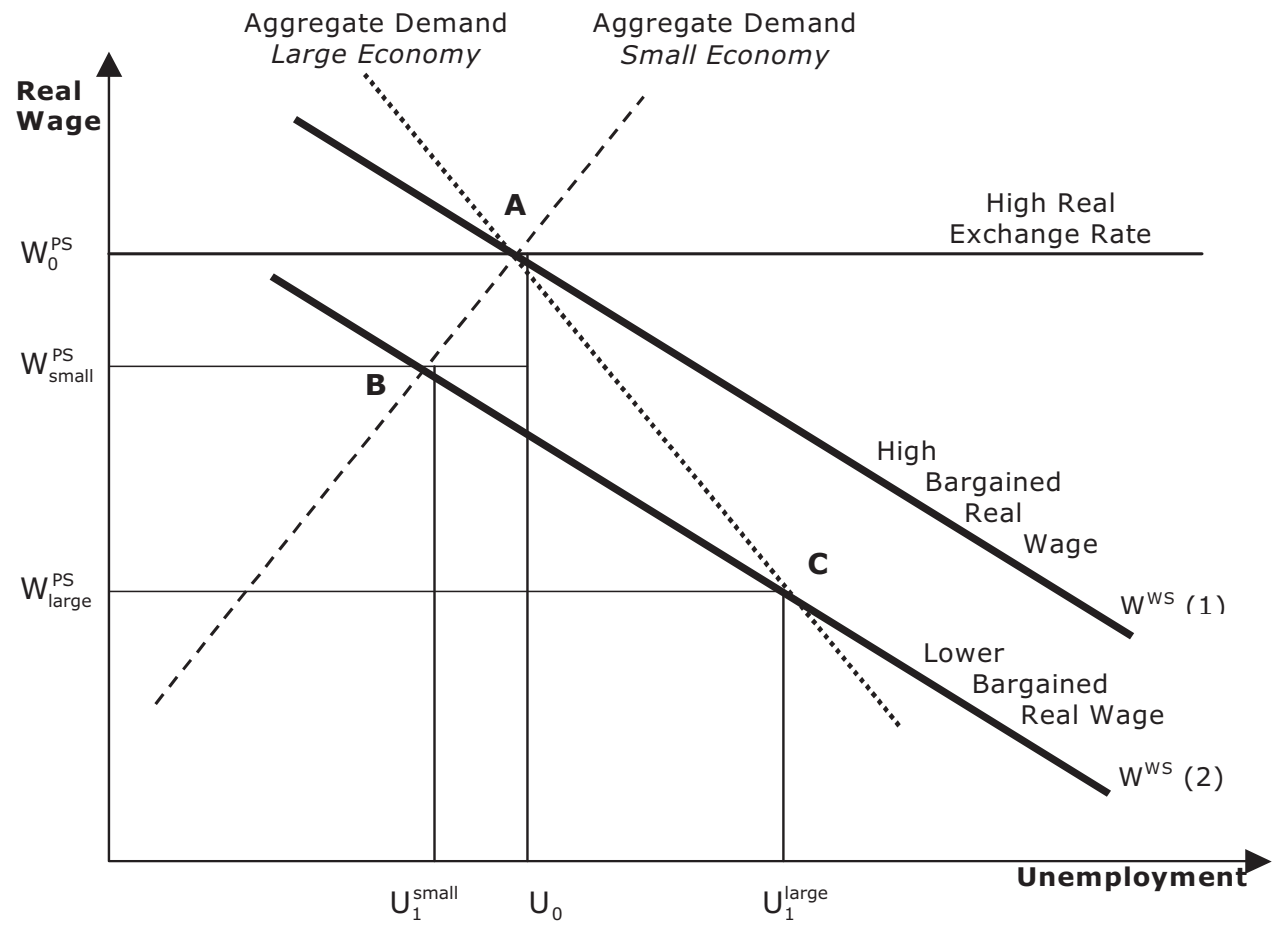

In a large economy the downward shift of the wage setting curve WS (from initial to restrained) leads to both lower income and lower domestic demand (A to C). In the large economy, the negative impact dominates and unemployment rises $\left(\mathrm{U}_{0}\right.$ to $\left.\mathrm{U}_{1}{ }^{\text {large }}\right)$. The opposite result is derived in the graph for a small open economy ( $A$ to $B$; $\mathrm{U}_{0}$ to $\mathrm{U}_{1}$ small). The key assumption here is that the aggregate demand curve is negatively sloped in a large economy. Hence labour market reforms could easily lead to the contrary of the intended effects, if demand is not taken into account appropriately. Simulations with an econometric model for Germany (with a New Keynesian employment function) confirm this view (Horn 2006). In the simulation the impact of reforms led to a decrease of consumption and domestic demand by about 1 percentage point. This negative effect more than compensated the improved export performance due to reduced labour costs. In this case it is advisable that labour market reforms should be accompanied by an expansionary macroeconomic policy to offset the immediate ad- 
verse demand effects. This would help to avoid possible adjustments producing a lower equilibrium (demand) level. This view is also shared by the OECD in its revised jobs study (OECD 2006). Therefore, from a theoretical point of view, the inclusion of demand features casts doubts on the assumption of unanimously positive employment effects of labour market reforms.

In order to assess the effectiveness of the labour market reforms one has to analyse the economic performance of the German economy during the slump and the consecutive upturn to identify the causes and roots of the employment expansion.

\section{Have the reforms strengthened employment growth?}

To properly assess the success or failure of reforms with respect to employment it is not sufficient to observe recent employment developments. It is not surprising that employment increases during an economic upturn. The important question is, does it increase more strongly or faster than in earlier cycles?

Since employment started to grow again, the majority of German economists have tried to attribute the positive development to the recent reforms. Thus the Deutsche Bundesbank (2007: 47-48) identifies the extended period of wage moderation and the structural labour market reforms as the reason behind the favourable employment trends since 2006. This institution supports its hypothesis only by a graph of GDP and hours worked across four business cycles, of which two concern pre-unification West Germany (starting in 1975Q2 and 1982Q3). The other two cycles, which refer to the whole of Germany, begin in 1993Q1 and 2000Q2, respectively. There is no documentation of the methodology behind this choice of business cycle dating. On the basis of a similar business cycle dating, RWI (2007) reaches the same conclusions. The RWI reports to have used estimations of the trend deviation of GDP to determine the turning points. Unfortunately, the trend concept that was applied is not defined in the report. In contrast to the Bundesbank, the RWI relies on the number of employees rather than hours worked. Nevertheless, the researchers derive the same conclusions: the most recent cycle shows a similar economic dynamic as previous ones, but employment rises faster.

Other institutions have identified different turning points. They define the periods from 1998 to 2000 and from 2004/2005 to 2007 as the two most recent upswings. For example the IAB (Bach et al. 2007, p. 2) compares various employment indicators for these two periods: hours worked, employment (persons), number of "minijobs", number of full-time and part-time employees, number of temporary employees. The IAB's analysis shows that the share of temporary employees has more than quadrupled compared to the previous business cycle, although employment itself has increased more slowly than in the previous cycle (1998-2000: +1.2 million persons; 2005-2007: +0.9 million persons). However, the total amount of hours worked rose more rapidly due to the increase in full-time employment. The IAB compares the two cycles on the basis of annual data. This approach can be criticised: annual growth rates may indicate an increase, when there is already a decline and vice versa. This is due to a statistical effect known as carry-over.

The Council of Economic Advisors (SVR 2007, Ziffer 481-498) also devotes a chapter to a business cycle analysis in its most recent report. It is similar in spirit to the 
analysis of Horn et al. (2007). The dating of the SVR is based on univariate filters which are applied to the seasonally and calendar-adjusted GDP. An output gap is derived using the average of these filters. Applying ad-hoc criteria too (minimum/maximum phase and cycle lengths), the SVR determines roughly the same business cycles as Horn et al. (2007) with the following troughs: 1993Q2, 1999Q2 and 2004Q4. However, the first cycle is not taken into account. Due to its proximity with the reunification it may be distorted. Thus, only the two most recent cycles are compared. As our dating is very close to that of the SVR, the results do not differ much either, although the interpretations do.

The comparison is based on quarterly seasonally and calendar adjusted time series. There are several approaches for the dating of business cycles. The NBER's method relies on monthly data for several indicators (production index, employment, unemployment, sales etc.). Upswings and downturns are defined whenever the tendency can be observed across the whole economy and continues long enough. Although it relies on a computer procedure, the NBER's approach is not purely mechanic, but relies on the judgement of experts (NBER 2003). An alternative is the widely accepted rule of thumb that two consecutive quarters of negative growth rates constitute a recession. For Germany this was the case in mid 1992, at the beginning of 1996, in 2002/03 and at the beginning of 2004. The European Commission has developed a software package for business cycle dating (BUSY). This programme is only applied to detrended series. There are several options (linear trend, quarterly and annual growth rates, Hodrick-Prescott filter, Baxter-King filter). Each approach yields

Table 1: Dating of business cycles

\begin{tabular}{|c|c|c|c|}
\hline & \multicolumn{2}{|c|}{ Germany (1991-2007) } & \multirow[b]{3}{*}{ Notes } \\
\hline & \multicolumn{2}{|c|}{ Business cycle dating with BUSY } & \\
\hline & Trough & Peak & \\
\hline \multirow[t]{4}{*}{ quarterly growth rates } & 1992 q4 & 1993 q4 & \\
\hline & 1995 q4 & 1997 q1 & \\
\hline & 1998 q1 & 1999 q3 & \\
\hline & $2002 q 4$ & 2006 q1 & includes a recession \\
\hline \multirow[t]{3}{*}{ annual growth rates } & 1992 q1 & 1993 q1 & \\
\hline & 1995 q1 & 1999 q1 & \\
\hline & 2002 q2 & 2005 q3 & includes a recession \\
\hline \multirow[t]{3}{*}{ Hodrick-Prescott filter } & 1993 q2 & 1995 q2 & \\
\hline & 1997 q1 & 2001 q1 & \\
\hline & $2004 q 4$ & -- & \\
\hline \multirow[t]{4}{*}{ Baxter-King filter } & 1993 q2 & 1995 q1 & \\
\hline & 1996 q2 & 1998 q1 & \\
\hline & 1999 q1 & 2000 q3 & \\
\hline & 2005 q2 & -- & \\
\hline \multirow[t]{2}{*}{ linear trend } & 1993 q2 & 2000 q2 & includes a recession \\
\hline & 2005 q1 & -- & \\
\hline
\end{tabular}

Source: Calculations of the authors based on official GDP statistics (Destatis) and the software package BUSY (JRC, European Commission).

Note: recession two consecutive quarters of negative qoq-GDP growth rates): $1992 q 2+3 ; 1995 q 4+1996 q 1 ; 2002 q 4+2003 q 1+2$; $2004 q 2+3$ 
a different result (cf. table 1). Business cycle dating is thus always arbitrary. In this paper the automated dating procedure has been amended with judgement. The result has to be plausible, yielding a reasonable number of cycles. In addition there should be no technical recessions in an upswing. On the basis of the BUSY-results and a graphical analysis, we have dated the two most recent business cycles as follows: 1998Q22001Q1 (“Cycle 1") 33 and 2004Q4-present (“Cycle 2").

The reason is that the evolution of GDP during the two periods is rather similar (cf. table 2 and figure 3), which makes it easier to interpret the differences in the evolution of alternative employment measures. The most important variables are given in Table 2 .

Table 2:

\begin{tabular}{|c|c|c|c|c|}
\hline & \multicolumn{2}{|c|}{$\begin{array}{c}\text { Cycle I } \\
\text { 1998Q2-2001Q1 }\end{array}$} & \multicolumn{2}{|c|}{$\begin{array}{c}\text { Cycle II } \\
\text { 2004Q4-2007Q3 }\end{array}$} \\
\hline & \multicolumn{4}{|c|}{ Accumulated change over 11 quarters } \\
\hline & in $\%$ & million persons & in $\%$ & million persons \\
\hline Real GDP & 7.10 & & 7.21 & \\
\hline Hours worked (employees and self-employed) & 1.32 & & 2.38 & \\
\hline Hourly labour productivity & 5.78 & & 4.83 & \\
\hline Employment & 3.99 & 1,508 & 2.25 & 874 \\
\hline Self-employed & 2.48 & 96 & 3.87 & 166 \\
\hline of which: not subsidised 1 & 2.67 & 102 & 5.52 & 221 \\
\hline Employees & 4.16 & 1,412 & 2.05 & 708 \\
\hline of which: "minijobs" 2 & & 441 & & 59 \\
\hline of which: "one-euro-jobs" (AGH-Mehraufwand) & & $X$ & & 254 \\
\hline of which: regular employment & 2.51 & 684 & 2.53 & 667 \\
\hline of which: not subsidised ${ }^{3}$ & 2.42 & 653 & 2.95 & 772 \\
\hline Working age population & 1.00 & 439 & -0.10 & -47 \\
\hline Unemployed (definition of the Federal Employment Agency) & & -554 & & -737 \\
\hline Unemployed (definition of the ILO) & & -643 & & -810 \\
\hline memorandum items: & & & & \\
\hline Real hourly labour cost (GDP deflator) & 6.06 & & -0.11 & \\
\hline Real net hourly wages (HICP) & 6.00 & & -4.19 & \\
\hline Profit income share (in \% of national income) & $-0.61^{4}$ & & $4.10^{4}$ & \\
\hline
\end{tabular}

1 i.e. Eexcluding measures to enhance self-employment such as: Überbrückungsgeld, Existenzgründungszuschuss (=Ich-AG), Einstiegsgeld (Selbstständigkeit) and Gründungszuschuss.

${ }^{2}$ Ausschließlich geringfügig Beschäftigte (i.e. exclusively working in a "minijob"); Cycle I: 1999Q2-2001Q1.

${ }^{3}$ Excluding subsidised employment (ABM, SAM, BSI), PSA, Kurzarbeit in full-time eq. and AGH-Entgelt.

$4 \%$ points.

Sources: Destatis, Bundesagentur für Arbeit, Bundesbank, IAB; Calculations of the authors.

It turns out that the number of hours worked is higher in the present cycle (Cycle 2) compared to the preceding (Cycle 1).

3 To ensure that results remain robust, the analysis is carried out for alternative business cycle dates. For the cycle preceding the current one the following quarters were chosen as alternative beginnings of the upswing: 1997Q1, 1998Q2 and 1999Q2. 
Figure 3: Cycle comparison

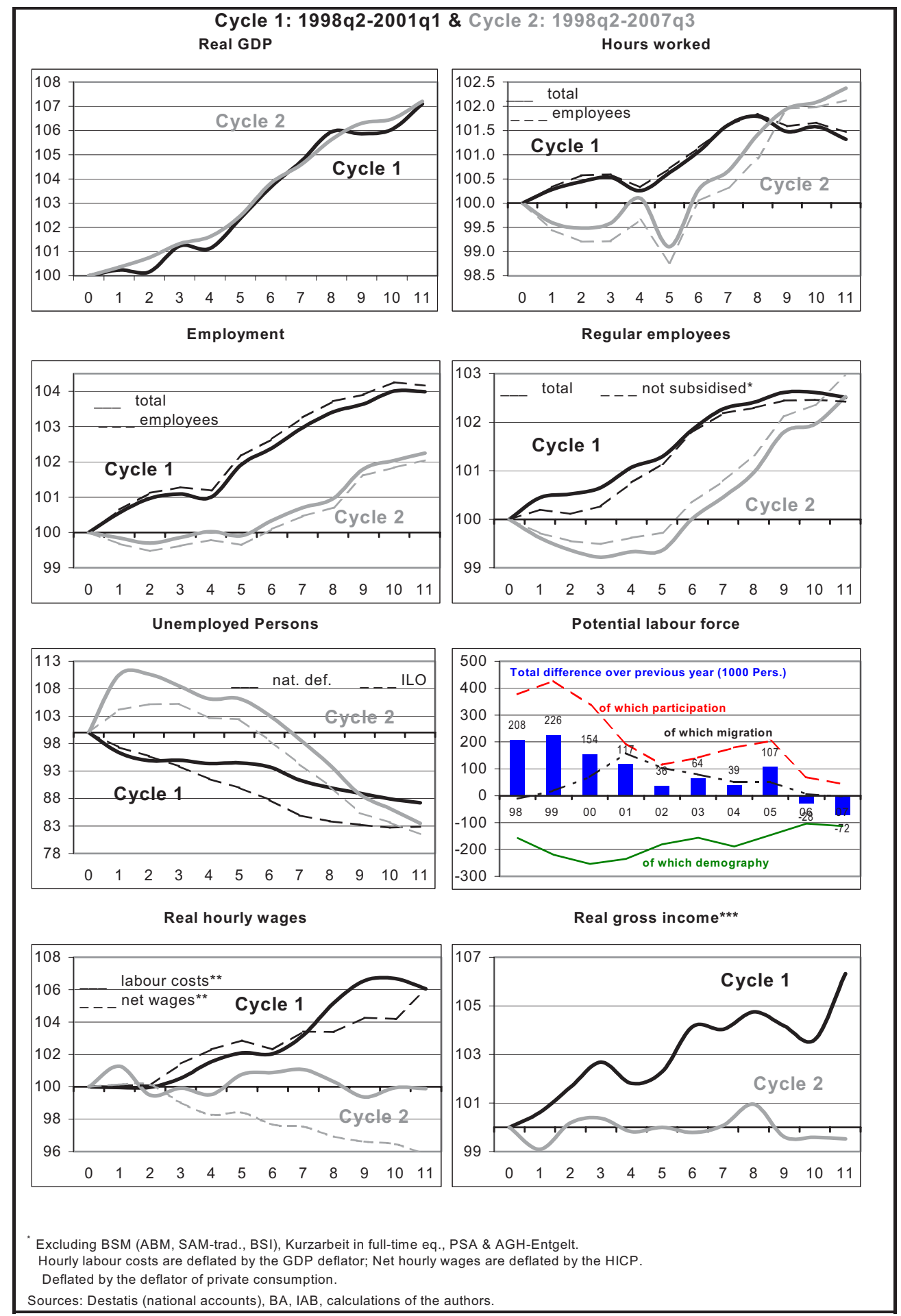


Whereas the evolution of GDP is very similar in both cycles, employment growth differs substantially. In Cycle 2 employment hardly rose at all during the first 7 quarters of the upswing. This is a clear indication that the upturn did not start in the labour market - as one may have expected from the above-mentioned mainstream theory. According to supply side approaches one would have expected that wage pressures triggered by the reforms would have led to higher employment even before production started to pick-up. That has clearly not happened, employment followed production instead - the usual pattern of the past.

In terms of persons employed, the labour market performance was much weaker in Cycle 2 than in Cycle 1. One reason is the surge in "minijobs" in the years 19992000 and other forms of subsidised employment that heavily distorted the picture at the turn of the millennium. Then firms obviously tended to create new jobs as "minijobs" rather than regular jobs. Thus, in Cycle 1 the lower dynamic should have been understated by the surge of the "minijobs" used as substitutes for regular jobs during the first years. That may also have had a negative influence on the number of hours worked, since the substitution will have been accompanied by a rationalisation of labour input. As result the number of hours worked is relatively small for the past cycle and the number of people employed relatively high. Consequently it is not surprising that the increase in hours worked is relatively high in the recent cycle compared to the preceding one and the increase in the number of employed persons is relatively small.

If one compares the evolution of regular employment over the two cycles, the increase achieved after 11 quarters is higher in Cycle 2, although it took more than $1 \frac{1}{2}$ years until the economic recovery reached the labour market. The picture looks brighter, when you look at unemployment. However, here one has to take the more favourable context of Cycle 2 into account, when the labour force declined whereas it rose in the preceding cycle. Thus the difference in the unemployment dynamics is mainly a consequence of changes in the labour supply. Additionally it should be mentioned that the unemployment statistics changed heavily as a consequence of Hartz III and IV (see IMK 2005: 16-17). Corrected for this effect, the reduction of unemployment in the current cycle has not been more impressive than in the preceding one. The two cycles show more or less identical transitions from unemployment to employment (Horn et al. 2007). The differences between our analysis and that of the SVR - which also uses the official BA data - show above all that the quality of the data on unemployment provided by this institution has changed enormously since 2005, which actually calls into question all comparisons over several years. Any data thus has to be interpreted with great care. Unfortunately, the compilation methods of the unemployment statistics (ILO concept) were also changed in 2005. This has to be kept in mind in any analysis of the German labour market.

A comparison of the respective indicators of the functional income distribution shows that in Cycle 2 the trends towards more income inequality and wage moderation continue. The real hourly net wages are declining in Cycle 2, whereas they increased in Cycle 1. Real labour costs are stagnating. The labour income share declined during the most recent two years, whereas it increased between 1998 and 2000 (Cycle 1). Real gross income of households has not risen either, but even declined slightly in the current upswing (Cycle 2). This is not primarily the consequence of inflation, 
but rather of an extended period of wage moderation. In combination with an elevated savings rate and less dynamic government transfers this explains sufficiently, why private final consumption expenditure lags so much behind the current GDP growth in Germany (Horn et al. 2008). Thus, we can conclude that the reforms have for the time being - had mixed effects on employment growth ${ }^{4}-$ a higher number of hours worked, lower number of jobs and less labour intensive growth; All in all, a return to normality after the stabilisation of the "minijobs". Moreover, the labour income share continues to decline and forms of underemployment and precarious employment continue to spread and concern a significant share of the German employment. The reforms have enhanced the tendency that already dominated economic development in Germany during most recent two decades and what they targeted as intermediate goal: wage restraint and increasing income inequality.

\section{Institutional origins of wage restraint}

The reforms of the German labour market already started during the 1990s (Bassanini/Duval 2006). The reform process reached its climax with the so-called "Agenda 2010" and the "Hartz laws" (I-IV). 5 It has to be noted that the reforms have affected all aspects of the German labour market: employment protection, regulations of parttime employment (generally in favour of employees) and fixed-term/temporary employment (liberalisation of fixed term contracts in 2003 and complete deregulation of temporary work in 2004, when all restrictions were lifted). Certain forms of employment were strongly affected by new instruments of active labour market policy. They include self-employment, atypical and "precarious" employment (such as "one-eurojobs", "minijobs" and "midijobs"). The reorganisation of the unemployment insurance system initiated by the Hartz laws, aimed at a general reduction of the generosity of the system (reduction of the level and duration of unemployment benefits, tougher sanctions and stricter controls). The law known as Hartz IV combines welfare ("Sozialhilfe") and unemployment benefits for long-term unemployed in the newly created unemployment benefit II (“Arbeitslosengeld II").

The decline of union membership, which is reflected both in the falling share of employees covered by collective agreements as well as in an increased downward flexibility of collective agreements, ${ }^{6}$ can be explained by several factors. An important factor is the expansion of the service sector in the German economy. Businesses in this sector are generally smaller, they have a higher share of part-time employees as well as women and young workers. Thus, the sector shows the typical characteristics of low-paid employment, which is not covered by collective agreements. The so-called "minijobs", low-paid part-time jobs, which have surged since their reform in 1999, are typically concentrated in the service sector. In connection with this first factor one can

$4 \quad$ For another study drawing the same conclusions see Schettkat (2006).

5 For a complete survey of reform measures, not only Hartz, cf. Deutsche Bundesbank (2005b: 25).

6 Based on WSI data on collectively agreed wages per hour (Bispinck 2007) in various industries as a percentage of the median wage and on the increase of working hours and working time flexibilisation as well as the use of working time accounts (Bispinck 2005). 
mention the effects of globalisation. Via outsourcing of production stages it either reduces the workforce in industry or imposes less favourable working conditions on the employees. A second factor is the deregulation and privatisation of the public utilities (mail services, telecommunication, energy). A third factor is the restructuring of large industrial companies that outsource certain activities to small independent businesses These businesses usually do not have any forms of co-determination or union representation. A last factor is the declining support of trade unions and collective agreements in academic and political circles (Bispinck 2003). In a context of mass unemployment, supply side theories gained ground and the dismal economic performance was increasingly blamed on high labour cost. These factors largely explain the evolution of German wages and salaries and the rising inequality, which are analysed in greater detail in the following paragraphs.

By means of the reform laws aiming at the deregulation of atypical employment the German legislature has actively pursued the creation of jobs in this segment of the labour market. ${ }^{7}$ The idea behind this approach, as already mentioned earlier, was that atypical employment represented an unrealised potential and that the major causes of the German unemployment consisted in rigid structures and excessively high wages, which would be counteracted by an expansion of atypical employment.

The share of temporary employment more than quintupled between 1994 and the mid 2007 (from $0.5 \%$ to $2.6 \%$ according to the $\mathrm{BA}^{8}$ ) and corresponded to more than 730,000 persons (with an upward trend) at the mid of 2007. Although the share of this form of employment is still relatively small, it plays an important part in the phenomenon of outsourcing. When companies transfer their employees to "independent" temp agencies, collective agreements no longer apply to the employees and workingconditions as well as wages and salaries usually deteriorate durably (Nienhüser/ Matiaske 2003; Promberger 2006).

Fixed-term employment has also increased quite strongly: although it declined between 2000 and 2002, it amounted to 14.6\% of total employment in 2007 (Eurostat) 9 Part-time employment has equally expanded rapidly, mostly due to the surge in "minijobs", which are by definition part-time jobs. Even without "minijobs" and "oneeuro-jobs", part-time employment has risen very fast. Its share increased from $13.4 \%$ in 1999 to $17.7 \%$ in the mid 2007 (BA).

Besides the development of atypical and precarious employment, the most striking consequence of the policy of labour market deregulation is the extraordinary increase of "minijobs" and other subsidies to low wages and salaries. "Minijobs" are synonymous with low and very low wages (Bosch/Kalina 2007) and have generally increased downward wage pressure. With reduced social insurance contributions "minijobs" and "midijobs" (gross wage/salary between 0 and $800 €$ per month) are actually subsidised forms of employment. The fact that low-paid jobs (less than $2 / 3$ of the

For an overview of trends in atypical employment in Germany cf. Keller/Seifert (2007).

8 Federal Employment Agency (Bundesagentur für Arbeit).

9 Using data from Destatis that exclude internship-jobs that are per nature fixed-term contract jobs yield the same qualitative results cf. Keller/Seifert (2007). 
median hourly wage) are over-represented in these forms of employment, suggests that mainly the employers benefit from the subsidies via lower gross wages. This system thus exerts downward wage pressure and it can be assumed that a significant number of regular (i.e. subject to compulsory social insurance) full-time jobs have been replaced by "minijobs" and to a lesser extent by "midijobs" in the years following the reform, at least the one of 2003 (Rudolph 2003; SVR 2004, Kasten 12). There is however a controversial debate on this subject: cf. Bundesagentur für Arbeit (2004) and Deutsche Bundesbank (2005a: 40-41) for two differing views.

The influence of reduced social security contributions on the wage level is wellexamined in France. This kind of subsidies tends to create a low-wage trap (L'Horty 2006; Rémy 2005). In Germany the situation is even more serious, because of the lack of a minimum wage that would serve as a lower limit. Instead, since 2005, the regulations of the Hartz IV law provide incentives for employers to lower wages further - at the expense of the state budget, because the unemployment benefit II (ALG II) also functions as a wage subsidy. Actually an unemployed person receiving the unemployment benefit II can work up to 15 hours per week without losing her/his status as unemployed person. The first 100 euros (net) are completely deducted from the income that serves as a calculation basis for the unemployment benefit. For the next income bracket ( $€ 100.01$ to $€ 800.00$ ) 20\% are deducted and for the last income bracket (€ 800.01 to $€ 1200.00) 10 \%$ can be deducted. All income exceeding $€ 1200.00$ is fully taken into account in the calculation of the unemployment benefit II. The income brackets and benefit payments depend on the family status. Thus, the unemployment benefit II partly serves as a subsidy to low wages (in addition to the reduced social insurance contributions for "minijobs" and "midijobs"). If the weekly working time exceeds 15 hours the person is no longer counted as unemployed but can continue to receive the unemployment benefit II in line with the regulations outlined above. In March 2007, 1.15 million people received the unemployment benefit II in addition to a working income of their own. Of these, 740,000 were not counted as unemployed, suggesting that they worked more than 15 hours/week (BA, November 2007).

\section{Conclusion - Domestic weakness and export strength}

Recent reforms have reshaped the labour market in Germany significantly. A major consequence is a rising inequality between wage earners and profit incomes as well as among wage earners (European Commission 2005, Chap. 4; Brenke 2007; SVR 2007, Zi. 718; Kalina/Weinkopf 2008). This impact had a major adverse impact on the economic performance of Germany in recent years. Since the middle of the 1990s the German economy had seen a growth performance that was much weaker than that of the rest of the euro area. After the turn of the millennium, Germany even suffered an extended period of stagnation. From 2002 to 2005 the budget deficit exceeded the limit defined by the Stability and Growth Pact, employment fell for several years, whereas it rose in the rest of the monetary union both in terms of persons and hours worked. Unemployment reached a record level of 9.5\% (ILO concept) in 2004 (see table 3).

Thus, the German economy is characterised by a pronounced macroeconomic weakness during the most recent decade. However, a detailed analysis shows significant discrepancies between individual demand aggregates. The weak performance of 
the German economy mainly concerns domestic demand whereas foreign trade has flourished for years.

Table 3: The German economy compared to the euro area and France

\begin{tabular}{|c|c|c|c|c|c|c|c|c|}
\hline & $\begin{array}{l}\text { Euro area } \\
\quad(12)\end{array}$ & $\begin{array}{l}\text { Euro area } \\
\text { (excluding } \\
\text { Germany) }\end{array}$ & Germany & France & $\begin{array}{l}\text { Euro area } \\
\quad(12)\end{array}$ & $\begin{array}{l}\text { Euro area } \\
\text { (excluding } \\
\text { Germany) }\end{array}$ & Germany & France \\
\hline & \multicolumn{4}{|c|}{ Growth rate of real GDP in \% } & \multicolumn{4}{|c|}{$\begin{array}{l}\text { Contribution of domestic demand } \\
\text { to GDP growth in \%-points }\end{array}$} \\
\hline 1996 & 1.5 & 1.7 & 1.0 & 1.1 & 1.1 & 1.5 & 0.4 & 0.7 \\
\hline 1997 & 2.6 & 2.9 & 1.8 & 2.2 & 2.0 & 2.5 & 0.9 & 1.0 \\
\hline 1998 & 2.8 & 3.2 & 2.0 & 3.5 & 3.5 & 4.1 & 2.3 & 4.0 \\
\hline 1999 & 3.0 & 3.5 & 2.0 & 3.3 & 3.5 & 3.9 & 2.6 & 3.7 \\
\hline 2000 & 3.8 & 4.1 & 3.2 & 3.9 & 3.3 & 3.8 & 2.1 & 4.2 \\
\hline 2001 & 1.9 & 2.2 & 1.2 & 1.9 & 1.2 & 2.0 & -0.5 & 1.7 \\
\hline 2002 & 0.9 & 1.2 & 0.0 & 1.0 & 0.4 & 1.4 & -2.0 & 1.1 \\
\hline 2003 & 0.8 & 1.2 & -0.2 & 1.1 & 1.4 & 1.8 & 0.6 & 1.7 \\
\hline 2004 & 2.0 & 2.4 & 1.1 & 2.5 & 1.8 & 2.6 & -0.2 & 3.2 \\
\hline 2005 & 1.5 & 1.7 & 0.8 & 1.7 & 1.7 & 2.2 & 0.3 & 2.3 \\
\hline \multirow[t]{2}{*}{2006} & 2.8 & 2.7 & 2.9 & 2.0 & 2.5 & 2.8 & 1.8 & 2.4 \\
\hline & \multicolumn{4}{|c|}{ Unemployment rate (ILO) in \% } & \multicolumn{4}{|c|}{$\begin{array}{l}\text { Contribution of net exports } \\
\text { to GDP growth in \%-points }\end{array}$} \\
\hline 1996 & 10.6 & 11.4 & 8.7 & 11.6 & 0.4 & 0.2 & 0.6 & 0.4 \\
\hline 1997 & 10.6 & 11.2 & 9.3 & 11.5 & 0.6 & 0.4 & 0.9 & 1.3 \\
\hline 1998 & 10.1 & 10.5 & 9.1 & 11.1 & -0.7 & -0.9 & -0.3 & -0.5 \\
\hline 1999 & 9.2 & 9.6 & 8.2 & 10.5 & -0.5 & -0.5 & -0.6 & -0.4 \\
\hline 2000 & 8.3 & 8.6 & 7.5 & 9.1 & 0.5 & 0.3 & 1.1 & -0.3 \\
\hline 2001 & 7.8 & 7.9 & 7.6 & 8.4 & 0.7 & 0.2 & 1.7 & 0.1 \\
\hline 2002 & 8.3 & 8.3 & 8.4 & 8.7 & 0.5 & -0.1 & 2.0 & 0.0 \\
\hline 2003 & 8.8 & 8.6 & 9.3 & 9.5 & -0.6 & -0.6 & -0.8 & -0.6 \\
\hline 2004 & 8.9 & 8.6 & 9.7 & 9.6 & 0.2 & -0.2 & 1.3 & -0.7 \\
\hline 2005 & 8.9 & 8.2 & 10.7 & 9.7 & -0.2 & -0.5 & 0.5 & -0.6 \\
\hline \multirow[t]{2}{*}{2006} & 8.3 & 7.7 & 9.8 & 9.5 & 0.2 & -0.1 & 1.1 & -0.4 \\
\hline & \multicolumn{4}{|c|}{$\begin{array}{l}\text { Employment growth (persons, national accounts) } \\
\text { in } \%\end{array}$} & \multicolumn{4}{|c|}{ Employment growth (hours worked) in \% } \\
\hline 1996 & 0.5 & 0.9 & -0.3 & 0.4 & & & -1.3 & 0.7 \\
\hline 1997 & 0.9 & 1.3 & -0.1 & 0.4 & 0.4 & 0.8 & -0.7 & 0.1 \\
\hline 1998 & 1.9 & 2.2 & 1.2 & 1.5 & 1.9 & 2.3 & 0.8 & 0.8 \\
\hline 1999 & 2.0 & 2.2 & 1.4 & 2.0 & 1.6 & 2.0 & 0.6 & 1.6 \\
\hline 2000 & 2.4 & 2.7 & 1.9 & 2.7 & 1.2 & 1.5 & 0.6 & 0.2 \\
\hline 2001 & 1.5 & 2.0 & 0.4 & 1.8 & 1.2 & 1.9 & -0.6 & 1.0 \\
\hline 2002 & 0.6 & 1.1 & -0.6 & 0.6 & -0.2 & 0.2 & -1.4 & -2.0 \\
\hline 2003 & 0.4 & 1.0 & -0.9 & 0.1 & 0.1 & 0.6 & -1.4 & -0.2 \\
\hline 2004 & 0.9 & 1.1 & 0.4 & 0.1 & 1.1 & 1.3 & 0.6 & 1.9 \\
\hline 2005 & 0.9 & 1.2 & -0.1 & 0.4 & 0.2 & 0.4 & -0.6 & -0.1 \\
\hline \multirow[t]{2}{*}{2006} & 1.5 & 1.8 & 0.6 & 0.8 & & & 0.5 & \\
\hline & \multicolumn{4}{|c|}{ Share of part-time employment $\%$} & \multicolumn{4}{|c|}{ Budget balance $^{a)}$ in $\%$ of GDP } \\
\hline 1996 & 14.1 & & 16.5 & 16.0 & -4.2 & -4.7 & -3.3 & -4.0 \\
\hline 1997 & 14.8 & & 17.5 & 16.8 & -2.6 & -2.6 & -2.6 & -3.0 \\
\hline 1998 & 15.4 & 14.0 & 18.3 & 17.2 & -2.2 & -2.3 & -2.2 & -2.6 \\
\hline 1999 & 17.3 & 14.3 & 19.0 & 17.3 & -1.3 & -1.3 & -1.5 & -1.7 \\
\hline 2000 & 17.6 & 14.6 & 19.4 & 16.9 & 0.0 & -0.5 & 1.3 & -1.5 \\
\hline 2001 & 18.2 & 14.7 & 20.3 & 16.4 & -1.8 & -1.4 & -2.8 & -1.5 \\
\hline 2002 & 18.4 & 14.7 & 20.8 & 16.2 & -2.5 & -2.0 & -3.7 & -3.2 \\
\hline 2003 & 19.0 & 15.0 & 21.7 & 16.5 & -3.0 & -2.6 & -4.0 & -4.1 \\
\hline 2004 & 19.9 & 16.1 & 22.3 & 16.7 & -2.8 & -2.4 & -3.7 & -3.6 \\
\hline 2005 & 19.0 & 16.8 & 24.0 & 17.2 & -2.5 & -2.1 & -3.2 & -3.0 \\
\hline 2006 & 19.6 & 16.8 & 25.9 & 17.2 & -1.6 & -1.5 & -1.7 & -2.5 \\
\hline
\end{tabular}


Table 3 (continued)

\begin{tabular}{|c|c|c|c|c|c|c|c|c|}
\hline & $\begin{array}{l}\text { Euro area } \\
\quad(12)\end{array}$ & $\begin{array}{l}\text { Euro area } \\
\text { (excluding } \\
\text { Germany) } \\
\end{array}$ & Germany & France & $\begin{array}{l}\text { Euro area } \\
\quad(12)\end{array}$ & $\begin{array}{l}\text { Euro area } \\
\text { (excluding } \\
\text { Germany) }\end{array}$ & Germany & France \\
\hline & \multicolumn{4}{|c|}{ Per capita growth of real gross wages and salaries in $\%$} & \multicolumn{4}{|c|}{ Population growth in \% } \\
\hline 1996 & & & & & & & & \\
\hline 1997 & -0.1 & 0.8 & -1.4 & 0.7 & 0.3 & 0.3 & 0.3 & 0.3 \\
\hline 1998 & 0.3 & 0.4 & 0.3 & 1.4 & 0.3 & 0.3 & 0.2 & 0.3 \\
\hline 1999 & 1.0 & 1.1 & 0.8 & 1.7 & 0.2 & 0.3 & 0.0 & 0.4 \\
\hline 2000 & 0.7 & 1.1 & 0.0 & 1.2 & 0.3 & 0.4 & 0.1 & 0.5 \\
\hline 2001 & 0.3 & 0.5 & -0.1 & 1.0 & 0.4 & 0.5 & 0.1 & 0.7 \\
\hline 2002 & 0.2 & 0.4 & 0.0 & 1.6 & 0.5 & 0.6 & 0.2 & 0.7 \\
\hline 2003 & -0.1 & -0.2 & 0.2 & 0.3 & 0.6 & 0.7 & 0.2 & 0.7 \\
\hline 2004 & 0.0 & 0.7 & -1.2 & 1.3 & 0.6 & 0.8 & 0.0 & 0.7 \\
\hline 2005 & -0.4 & 0.2 & -1.7 & 1.1 & 0.6 & 0.9 & 0.0 & 0.6 \\
\hline \multirow[t]{2}{*}{2006} & 0.0 & 0.5 & -0.9 & 1.2 & 0.6 & 0.8 & 0.0 & 0.6 \\
\hline & \multicolumn{4}{|c|}{ Change of nominal unit labour cost in \% } & \multicolumn{4}{|c|}{$\begin{array}{c}\text { Growth rate of the working age (15-64 years) } \\
\text { population in \% }\end{array}$} \\
\hline 1996 & 1.5 & 2.3 & 0.0 & 1.3 & 0.2 & 0.3 & 0.2 & 0.3 \\
\hline 1997 & 0.3 & 1.1 & -1.1 & 0.0 & 0.3 & 0.3 & 0.2 & 0.3 \\
\hline 1998 & 0.3 & 0.3 & 0.1 & -0.1 & 0.2 & 0.3 & 0.0 & 0.3 \\
\hline 1999 & 1.0 & 1.4 & 0.4 & 1.0 & 0.2 & 0.3 & -0.1 & 0.4 \\
\hline 2000 & 1.1 & 1.4 & 0.6 & 1.2 & 0.2 & 0.5 & -0.3 & 0.5 \\
\hline 2001 & 2.2 & 3.0 & 0.8 & 2.3 & 0.3 & 0.6 & -0.2 & 0.6 \\
\hline 2002 & 2.4 & 3.1 & 0.8 & 3.0 & 0.4 & 0.7 & -0.1 & 0.7 \\
\hline 2003 & 1.9 & 2.5 & 0.8 & 1.8 & 0.4 & 0.7 & -0.3 & 0.7 \\
\hline 2004 & 1.0 & 1.6 & -0.3 & 1.1 & 0.3 & 0.6 & -0.5 & 0.6 \\
\hline 2005 & 1.1 & 2.1 & -1.0 & 1.8 & 0.3 & 0.6 & -0.3 & 0.6 \\
\hline \multirow[t]{2}{*}{2006} & 0.9 & 1.8 & -1.1 & 1.8 & 0.4 & 0.6 & -0.3 & 0.6 \\
\hline & \multicolumn{4}{|c|}{ Inflation rate $(\mathrm{HICP})$ in \% } & \multicolumn{4}{|c|}{ Real effective exchange rate ${ }^{\text {b) }}, 1996=100$} \\
\hline 1996 & & & & & 100.0 & & 100.0 & 100.0 \\
\hline 1997 & 1.7 & 1.7 & 1.5 & 1.3 & 90.7 & & 93.8 & 94.9 \\
\hline 1998 & 1.2 & 1.5 & 0.6 & 0.7 & 92.1 & & 94.4 & 95.7 \\
\hline 1999 & 1.1 & 1.4 & 0.6 & 0.6 & 90.3 & & 93.0 & 93.7 \\
\hline 2000 & 2.1 & 2.5 & 1.4 & 1.8 & 81.0 & & 86.7 & 88.4 \\
\hline 2001 & 2.4 & 2.8 & 1.9 & 1.8 & 81.9 & & 86.5 & 88.5 \\
\hline 2002 & 2.3 & 2.7 & 1.4 & 1.9 & 84.8 & & 87.3 & 90.0 \\
\hline 2003 & 2.1 & 2.6 & 1.0 & 2.2 & 94.2 & & 91.8 & 95.2 \\
\hline 2004 & 2.1 & 2.3 & 1.8 & 2.3 & 96.6 & & 93.0 & 96.8 \\
\hline 2005 & 2.2 & 2.3 & 1.9 & 1.9 & 94.0 & & 91.4 & 95.5 \\
\hline \multirow[t]{2}{*}{2006} & 2.2 & 2.4 & 1.8 & 1.9 & 92.9 & & 90.4 & 94.8 \\
\hline & \multicolumn{4}{|c|}{$\begin{array}{c}\text { Core inflation rate } \\
\text { (excluding energy, food, alcohol and tobacco) in \% }\end{array}$} & \multicolumn{4}{|c|}{ Long-term interest rate (10 years) in \% p.a. } \\
\hline 1996 & & & & & & & 6.2 & 6.3 \\
\hline 1997 & 1.6 & 1.7 & 1.3 & 0.8 & & & 5.6 & 5.6 \\
\hline 1998 & 1.5 & 1.8 & 1.0 & 0.8 & 4.7 & & 4.6 & 4.6 \\
\hline 1999 & 1.1 & 1.5 & 0.5 & 0.5 & 4.7 & & 4.5 & 4.6 \\
\hline 2000 & 1.0 & 1.5 & 0.2 & 0.4 & 5.4 & & 5.3 & 5.4 \\
\hline 2001 & 1.8 & 2.4 & 1.0 & 1.2 & 5.0 & & 4.8 & 4.9 \\
\hline 2002 & 2.4 & 2.9 & 1.4 & 2.0 & 4.9 & & 4.8 & 4.9 \\
\hline 2003 & 1.8 & 2.3 & 0.7 & 1.7 & 4.1 & & 4.1 & 4.1 \\
\hline 2004 & 1.8 & 2.0 & 1.5 & 1.8 & 4.1 & & 4.0 & 4.1 \\
\hline 2005 & 1.4 & 1.7 & 0.6 & 1.5 & 3.4 & & 3.4 & 3.4 \\
\hline 2006 & 1.4 & 1.7 & 0.7 & 1.4 & 3.8 & & 3.8 & 3.8 \\
\hline
\end{tabular}


Since 1996 German domestic demand grew by an annual average of $0.8 \%$ compared to $2.8 \%$ in the rest of the euro area. At $1.0 \%$ the average increase of private final consumption expenditure was the weakest of all euro area economies and explains a large part of the weak domestic demand.

Figure 4:

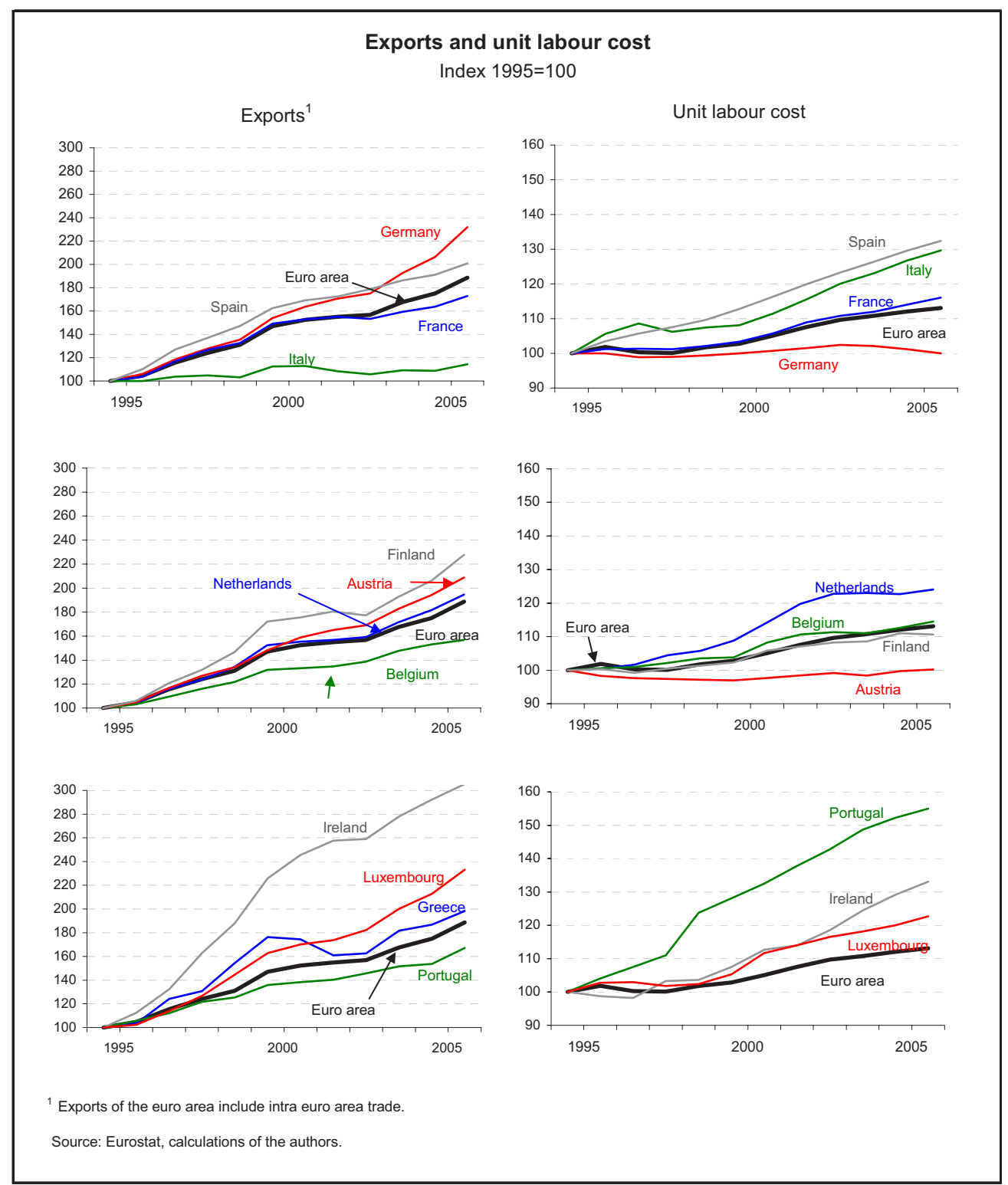

The only positive force has been foreign trade. Net exports have expanded rapidly since the middle of the 1990s. They have contributed almost as much to GDP growth 
as domestic demand, whereas for the rest of the euro area the growth contribution of net exports has been negative. In 2006 German net exports of goods and services amounted to 5.4\% of GDP. Only much smaller economies, such as the Netherlands, Austria, Finland, Ireland or Luxembourg have higher net exports relative to their GDP. For a country of the size of Germany, the foreign trade surplus is exceptional. Germany shows the largest discrepancy between internal demand and exports. Compared to German exports, imports rise only moderately. The main explanation for the unbalanced evolution of the German economy lies in the Germany's wage policies during the most recent ten years.

This split can only be explained by the outlined wage restraint enhanced by labour market reforms. The results show that the supposed advantages of the reforms in terms of wage moderation are there but the price of lost domestic growth is high.

\section{References}

Bach, Hans-Uwe / Gartner, Hermann / Klinger, Sabine / Rothe, Thomas / Spitznagel, Eugen (2007): Arbeitsmarkt 2007/2008 - Ein robuster Aufschwung mit freundlichem Gesicht. In: IAB Kurzbericht, 15: 1-8.

Bassanini, Andrea / Duval, Romain (2006): Employment Patterns in OECD Countries: Reassessing the Role of Policies and Institutions. In: OECD Social, Employment and Migration Working Papers, 35.

Bispinck, Reinhard (2003): Das deutsche Tarifsystem in Zeiten der Krise - Streit um Flächentarif, Differenzierung und Mindeststandards. In: WSI-Mitteilungen, 56(7): 395-404.

Bispinck, Reinhard (2005): Immer flexibler - und immer länger? Tarifliche Regelungen zur Arbeitszeit und ihrer Gestaltung. Eine Analyse von 24 Tarifbereichen. In: WSI-Tarifarchiv (ed.): Reihe: Elemente qualitativer Tarifpolitik, 57, Düsseldorf, Hans-Böckler-Stiftung.

Bispinck, Reinhard (2007): Unterste Tarifvergütungen 2007 - Ausgewählte Tarifbereiche mit unterster Tarifgruppe und Laufzeitende der Vergütungstarifverträge. In: WSI Tarifarchiv (ed.): Reihe: Elemente qualitativer Tarifpolitik, 63, Düsseldorf, Hans-Böckler-Stiftung.

Bosch, Gerhard / Kalina, Thorsten (2007): Niedriglöhne in Deutschland - Zahlen, Fakten, Ursachen. In: Arbeiten für wenig Geld - Niedriglohnbeschäftigung in Deutschland, Frankfurt/Main, Campus Verlag.

Brenke, Karl (2007): Zunehmende Lohnspreizung in Deutschland. In: DIW Wochenbericht, 74(6): 73-79.

Bundesagentur für Arbeit (2004): Mini- und Midijobs in Deutschland. In: Sonderbericht der Bundesagentur, 12, Nürnberg.

Carlin, Wendy / Soskice, David (1990). Macroeconomics and the Wage Bargain. A Modern Approach to Employment, Inflation, and the Exchange Rate. Oxford, Oxford University Press.

Carlin, Wendy / Soskice, David (2007): Reformen, makroökonomische Politik und Wirtschaftsentwicklung in Deutschland. In: Ronald Schettkat und Jochem Langkau (ed.): Aufschwung für Deutschland, Bonn, Dietz-Verlag.

Deutsche Bundesbank (2005a). Monatsbericht, (2). Frankfurt/Main.

Deutsche Bundesbank (2005b). Monatsbericht, (7). Frankfurt/Main.

Deutsche Bundesbank (2007). Monatsbericht, (8). Frankfurt/Main.

European Commission (2005): Employment in Europe 2005 - Recent Trends and Prospects. In: Directorate-General for Employment and Social Affairs. Brussels.

Horn, Gustav (2006): Structural Reforms and Macroeconomic Policy. In: Andrew Watt and Ronald Janssen (ed.): Delivering the Lisbon Goals. Brussels.

Horn, Gustav / Logeay, Camille/Stapff, Diego (2007): Viel Lärm um nichts? Arbeitsmarktreformen zeigen im Aufschwung bisher kaum Wirkung. In: IM-Report, (20).

Horn, Gustav / Logeay, Camille / Zwiener, Rudolf (2008): Wer profitierte vom Aufschwung? In: IMKReport, (27). 
IMK (Institut für Makroökonomie und Konjunkturforschung) (2005): Wirtschaftliche Entwicklung 2006: Vor schwierigen Weichenstellungen. In: IMK-Report, (3).

Kalina, Torsten / Weinkopf, Claudia (2008): Weitere Zunahme der Niedriglohnbeschäftigung: 2006 bereits rund 6,5 Millionen Beschäftigte betroffen. In: IAQ-Report, (1).

Keller, Berndt / Seifert, Hartmut (2007): Atypische Beschäftigungsverhältnisse: Flexibilität, soziale Sicherheit und Prekarität. In: Atypische beschäftigung - Flexibilisierung und soziale Risiken, Keller/Seifert (ed.), Hans-Böckler-Stiftung Nr. 83, Sigma, Wuppertal, , pp. 11-25.

L'Horty, Yannick (2006): Dix ans d'évaluation des exonérations sur les bas salaires. In: Connaissance de l'emploi, (24).

Layard, Richard / Nickell, Stephen / Jackman, Richard (1991). Macroeconomic Performance and the Labour Market. Oxford: Oxford University Press.

NBER (National Bureau of Economic Research) (2003): Memo of July 17th".

Nienhüser, Werner / Matiaske, Wenzel (2003): Der "Gleichheitsgrundsatz" bei Leiharbeit - Entlohnung und Arbeitsbedingungen von Leiharbeitern im europäischen Vergleich. In: WSI-Mitteilungen, 56(8).

OECD (1994): The OECD Jobs Study. In: Facts, Analysis, Strategies. Paris.

OECD (2006): Boosting Jobs and Incomes - Policy lessons from reassessing the OECD Jobs Strategy. In: OECD Employment Outlook. June, Paris.

Promberger, Markus (2006): Leiharbeit - Flexibilität und Prekarität in der betrieblichen Praxis. In: WSI Mitteilungen, 59(5).

Rémy, Véronique (2005): Eléments de bilan sur les travaux évaluant l'efficacité des allégements de cotisations sociales employeurs. In: DARES Working Paper, (101).

Rudolph, Helmut (2003): Mini- und Midi-Jobs: Geringfügige Beschäftigung im neuen Outfit. In: IABKurzbericht, (6).

RWI (Rheinisch-Westfälisches Institut für Wirtschaftsforschung) (2007): Konjunkturbericht, 58(2).

Schettkat, Ronald (2006): Lohnspreizung: Mythen und Fakten: Eine Literaturübersicht zu Ausmaß und ökonomischen Wirkungen von Lohngleichheit. Hans Böckler Stiftung (ed.): Düsseldorf (183).

Sinn, Hans-Werner (2003). Ist Deutschland noch zu retten? München/Berlin, Econ/Ullstein Verlag.

Sinn, Hans-Werner (2005). Die Basarökonomie. Berlin, Econ-Verlag.

Sinn, Hans-Werner / Holzner, Christian / Meister, Wolfgang / Ochel, Wolfgang / Werding, Martin (2006): Aktivierende Sozialhilfe. In: ifo Schnelldienst, (2), 3-24.

SVR (Sachverständigenrat) (2002): Sachverständigenrat zur Begutachtung der gesamtwirtschaftlichen Entwicklung: Zwanzig Punkte für Wachstum und Beschäftigung. In: Jahresgutachten 2002/2003, Wiesbaden.

SVR (Sachverständigenrat) (2004): Sachverständigenrat zur Begutachtung der gesamtwirtschaftlichen Entwicklung: Erfolge im Ausland - Herausforderungen im Inland. In: Jahresgutachten 2004/2005, Wiesbaden.

SVR (Sachverständigenrat) (2005): Sachverständigenrat zur Begutachtung der gesamtwirtschaftlichen Entwicklung: Die Chance nutzen - Reformen mutig voranbringen. In: Jahresgutachten 2005/2006, Wiesbaden.

SVR (Sachverständigenrat) (2007): Sachverständigenrat zur Begutachtung der gesamtwirtschaftlichen Entwicklung: Das Erreichte nicht verspielen. In: Jahresgutachten 2007/08, 11, Wiesbaden. 